\title{
Merawat Damai Antar Umat Beragama Melalui Memori Kolektif dan Identitas Kultural Masyarakat Maluku
}

\author{
Dewi Tika Lestari $^{*}$, Yohanes Parihala ${ }^{2}$ \\ 1 Institut Agama Kristen Negeri Ambon, Indonesia; e-mail: tiansparihala@gmail.com \\ 2 Universitas Kristen Indonesia Maluku, Indonesia; e-mail: parihalayoh@gmail.com \\ * Correspondence
}

Received: 2020-04-27; Accepted: 2020-06-05; Published: 2020-06-25

\begin{abstract}
This study aims to explain that the process of building and maintaining peace in the context of a plural society can be carried out by reactivating the collective memory and cultural identity of the community. Cultural memory and cultural identity that are based on historical-cultural experience are a social capital that nurtures harmony between communities. Qualitatively this study uses a literature study and field research approach. To explore the concepts of collective memory and cultural identity, author uses the concept from Edwards Shils, Maurice Halbwachs, and Paul Gilbert. The field study was obtained through a process of in-depth interviews with key informants, including religious leaders such as the Pastor and Imam of the Mosque, facilitators and community leaders in Batumerah from two communities, Islam and Christianity. Finally, the authors found that the collective memory of the cultural identity of Maluku people as brother people (orang basudara) is a strong social capital to transform conflict, and maintain peace among post-conflict communities. This can be a theoretical foothold in managing the diversity of peaceful lives as fellow brothers in Indonesia.
\end{abstract}

Keywords: Peace; Collective Memory; Cultural Identity; Maluku.

Abstract: Kajian ini bertujuan untuk menjelaskan bahwa proses membangun dan merawat perdamaian di dalam konteks masyarakat majemuk dapat dilakukan dengan mengaktifkan lagi memori kolektif dan identitas kultural masyarakat. Secara kualitatif kajian ini menggunakan pendekatan studi kepustakaan dan penelitian lapangan. Studi pustaka dilakukan dengan menganalisis konsep memori kolektif yang dijelaskan oleh Edward Shils dan Maurice Halbwachs, sedangkan konsep Identitas kultural berangkat dari gagasan Paul Gilbert. Kajian lapangan diperoleh melalui proses wawancara mendalam dengan para informan kunci, antara lain tokoh agama seperti Pendeta dan Imam Masjid, tokoh pemudah dan tokoh masyarakat di negeri Batumerah dari dua komunitas, Islam dan Kristen. Akhirnya, penulis menemukan bahwa ingatan bersama terhadap identitas budaya masyarakat Maluku sebagai orang basudara merupakan modal sosial yang kuat untuk mentransformasi konflik, dan merawat perdamaian di antara masyarakat pasca konflik. Hal ini dapat menjadi suatu pijakan teoritis dalam mengelola keberagaman hidup yang penuh damai sebagai sesama orang basudara di bumi Indonesia.

Keywords: Perdamaian; Memori Kolektif; Identitas Kultural; Maluku.

\section{Pendahuluan}

Kajian mengenai perdamaian (peace studies) telah banyak dilakukan oleh para peniliti dari berbagai perspektif, seperti sosial budaya, gender, politik, hukum dan agama (Buchanan \& Cooper, 2011; Duncan, 2016; Galtung, 1996; Meo, 2019; Schumann, 2011; Al-Qurtuby, 2013; Setyawan, 2017; Sabandar, Saimima, \& Parihala, 2020). Beberapa kajian juga berangkat dari proses transformasi konflik dan upaya perdamaian yang berhasil diwujudkan dalam konteks konflik Maluku (Al Qurtuby, 2013; Bräuchler, 2019; Iwamony, Gaspersz, \& Souisa, 2019; Manuputty, 2017; Jati, 2013; Mannitz, 2017). Kajian ini tidak 
lagi bertujuan mengulangi kajian-kajian sebelumnya, yang membahas proses mewujudkan perdamaian di Maluku berangkat dari keterlibatan pemerintah, tokoh agama, atau juga dengan menggunakan budaya lokal di dalam masyarakat. Perspektif lain yang digunakan di sini adalah mengenai suatu proses membangun dan merawat perdamaian dengan melibatkan memori kolektif dan identitas kultural masyarakat.

Kajian mengenai memori kolektif dan fungsinya dalam membentuk kembali identitas kultural masyarakat juga bukanlah sesuatu yang baru. Dewi Tika Lestari telah meneliti sebelumnya mengenai peranan musik lokal Maluku dalam menghidupkan memori kolektif masyarakat yang bertujuan untuk membangun perdamaian (Lestari, 2019). Penelitian lain tentang memori kolektif telah dilakukan oleh Georgia Foscarini yang mengkonstruksi suatu etnisitas dan identitas kultural berdasarkan ingatan bersama suatu kelompok masyarakat etnik (ethnology) (Foscarini, 2018). Selain itu, peran memori dalam perjumpaan antar agama yang bisa saling mengeklusikan karena ingatan bersama pada berbagai peristiwa kekerasan telah dibahas oleh Cahyo Pamungkas (Pamungkas, 2015). Berbeda dengan kajian yang disebutkan di atas, kajian ini merekonstruksi secara bersama memori kolektif dan identitas kultural antar komunitas umat beragama Kristen dan Islam di Batumerah, Kota Ambon, di dalam tiga fase waktu, yakni sebelum konflik, di masa konflik, dan pasca konflik Maluku. Memori yang terpisah oleh penggalan waktu dan peristiwa historisnya perlu dirajut untuk mecangkokkan (hybrid) kembali suatu identitas bersama yang bermakna bagi proses membangun dan merawat perdamaian hidup antar masyarakat.

Masyarakat Maluku yang telah keluar dan membangun perdamaian pasca konflik di tahun 19992004 masih menyimpan dalam memori kolektif mereka pengalaman konflik yang memilukan itu. Hal ini disebabkan oleh pengalaman kolektif terkait berbagai dampak destruktif dari konflik Maluku. Trijono menjelaskan bahwa konflik Maluku menimbulkan dampak kerusakan yang hebat di tengah komunitas masyarakat Maluku. Dampak konflik tersebut, antara lain menimbulkan korban kekerasan langsung, yaitu ribuan nyawa yang melayang, ribuan orang terluka dan ada yang cacat tubuh seumur hidup, ditambah dengan masyarakat Maluku yang menjadi pengungsi di tanah sendiri. Selain itu, ada pula dampak konflik tidak langsung, seperti kerusakan bangunan atau kerusakan fisik, kerusakan hubungan sosial masyarakat, krisis perekonomian dan menajamnya segregasi sosial masyarakat (Trijono, 2001).

Dalam aspek sosial budaya, konflik telah menciptakan pemilahan sosial dan mempertajam segregasi kelompok berdasarkan garis keagamaan, yang disertai menguatnya sentimen solidaritas kelompok. Kondisi ini semakin diperkuat dengan terbentuknya pemukiman-pemukiman segregasi sebagai akibat dari gelombang pengungsian masyarakat yang menjadi korban konflik. Sebelum konflik masih ditemukan pemukiman masyarakat yang berbaur dan hidup bersama pada satu tempat sekalipun berbeda agama. Namun konflik telah memaksakan masyarakat yang "kalah" atau "sedikit jumlahnya" dalam ruang hidup bersama untuk secara terpaksa meninggalkan tempat hunian dan rumah kehidupan mereka. Untuk menyelamatkan diri, para pengungsi ini kemudian direlokasikan ke wilayah pemukiman masyarakat yang memiliki kesamaan agama. Sebagai pengungsi, masyarakat masih hidup dengan berbagai masalah.

Memori dampak konflik ini dapat mencuat kembali di tengah konteks Maluku yang telah berdamai saat ini. Oleh karena itu, proses rekonstruksi identitas masyarakat Maluku pasca konflik perlu dibangun dengan menafsirkan pengalaman dan memori kolektif masyarakat pasca konflik. Hal ini dimaksudkan untuk menguji apakah masyarakat Maluku telah berhasil menyelesaikan dan berdamai dengan masa lalu yang kelam akibat konflik yang pernah dialami? Ataukah, pengalaman konflik masih tetap membekas menjadi potensi konflik terpendam, yang sewaktu-waktu dapat menjadi ancaman bagi kedamaian Maluku yang sedang dialami saat ini. Proses rekonstruksi dan pengujian kembali identitas kolektif masyarakat pasca konflik bertujuan untuk menjamin bahwa proses perdamaian Maluku dapat terus dirawat dan dipelihara oleh semua masyarakat kedepannya.

Konflik Maluku pertama kali terjadi di wilayah Batumerah. Sebelum konflik negeri Batumerah dihuni oleh komunitas masyarakat yang beragam agamanya, sepeti masyarakat Kristen dan Muslim yang hidup saling berdampingan. Mayoritas penduduk Kristen di Batumerah sebelum konflik 
merupakan warga Jemaat Gereja Protestan Maluku (GPM) Bethabara. Di negeri Batumerah, jemaat Bethabara sebelum konflik memiliki 8 sektor pelayanan yang tersebar hampir di semua RT/RW Batumerah. Hidup berdampingan dan berlaku sebagai sesama orang bersaudara sekalipun berbeda agama merupakan salah satu bentuk warisan memori kolektif masyarakat Batumerah. Di tengah situasi konflik memori ini sempat terkubur akibat provokasi dan eskalasi konflik yang meningkat. Namun, pengalaman hidup sebagai orang basudara yang telah terbingkai sejak para leluhur tentunya telah turut menjadi modal sosial membangun dan merawat perdamaian. Dengan demikian, penilitian ini pada akhirnya bertujuan untuk merefleksikan lagi suatu pengalaman dan ingatan kolektif terkait identitas kultural masyarakat Maluku sebagai sesama orang basudara yang dapat menjamin dan merawat perdamaian antar umat beragama di Maluku.

\section{Metode Penelitian}

Secara kualitatif, kajian ini menggunakan dua pendekatan yaitu studi kepustakaan dan penelitian lapangan. Studi kepustakaan dilakukan dengan cara menganalisis sejumlah referensi atau kajian-kajian sebelumya yang terkait dengan konsep memori kolektif dan identitas kultural. Kemudian melalui penelitian lapangan, penulis mengumpulkan dan menganalisis data berkaitan dengan pengalaman dan memori kolektif masyarakat yang mengalami secara langsung peristiwa konflik dan proses perdamaian di Maluku. Proses pengumpulan data dalam penelitian lapangan dilakukan melalui proses wawancara mendalam dengan beberapa informan kunci, seperti Pendeta I. Toisuta, Ketua Majelis Jemaat GPM Bethabara, dan Hj. Usman Oei selaku Imam Masjid Agung A'nur Batumerah, dan tokoh pemuda juga tokoh masyarakat dari dua komintas, yaitu warga jemaat GPM Bethabara dan Umat Muslim Batumerah. Kedua komunitas ini sebelum konflik menjalani hidup bersama di Desa Batumerah, wilayah di mana konflik Maluku pertama kali terjadi pada tahun 1999. Kini mereka telah menjalani hidup di wilayah yang terpisah, tetapi memori kolektif dan identitas bersama sebagai orang basudara terus terpatri di dalam sanubari, dan menjadi modal kultural merawat damai di Maluku.

\section{Konsep Memori Kolektif dan Identitas Kultural}

Pembahasan mengenai memori kolektif menggunakan gagasan dari Shils (Jacobs, 2007; Shils, 1971) mengenai memori sebagai rekaman masa lampau yang tersimpan di dalam diri manusia, dan gagasan dari Maurice Halbwachs mengenai The Social Frameworks of Memory dalam bukunya On Collective Memory (Halbwachs, 1992). Edward Shils menjelaskan bahwa memori merupakan suatu tempat dalam diri setiap manusia yang menyimpan di masa kini rekaman peristiwa-peristiwa di masa lampau baik yang dialami secara langsung maupun yang secara tidak langsung memiliki hubungan dengan identitas diri setiap manusia. Memori atau ingatan masa lampau dapat merasuk dalam sanubari seseorang atau suatu masyarakat, yaitu melalui kesan pertama yang menguak tentang identitas diri sendiri, baik individu maupun kolektif - yang merupakan sebagian persepsi sekarang tentang masa lampaunya (Jacobs, 2007; Shils, 1971).

Maurice Halbwachs menegaskan bahwa memori kolektif itu ada di dalam kehidupan masyarakat. Secara normal, manusia memerlukan memori mereka untuk meneguhkan kesadaran diri dan membentuk identitas diri di tengah situasi sosial yang selalu mengalami perubahan. Memori mengenai berbagai peristiwa di masa lampau tersimpan dalam sanubari masyarakat secara kolektif. Itu sebabnya kelompok masyarakat dapat memproduksi memori-memori pada setiap individu dari peristiwaperistiwa yang mereka tidak pernah alami secara langsung (Halbwachs, 1992). Gagasan dari Halbwachs dalam kajian ini menekankan bahwa memori kolektif masyarakat Maluku sebagai orang bersaudara tidak dapat diteliti di luar konteks masyarakat, sebab memori itu tersimpan dan terpelihara dalam kehidupan masyarakat Maluku. Fungsi memori kolektif yang dihidupkan itu adalah untuk mengaktifkan masa lalu sehingga dapat membentuk identitas kolektif kultural masyarakat (Halbwachs, 1992).

Paul Gilbert memberikan dua defenisi mengenai identitas kolektif kultural. Pertama, menunjuk kepada suatu identitas individu di dalam aspek-apek kulturalnya atau disebut identitas budaya individu. Kedua menunjuk pada identitas anggota suatu kelompok budaya tertentu. Identitas kultural 
yang melekat pada identitas individu relatif tidak bermasalah karena setiap individu akan memproduksi identitas dirinya sendiri di dalam aspek-aspek budaya, seperti bahasanya, agama, pendidikan moral, perilaku sosial, dan seterusnya. Gilbert menyetujui gagasan beberapa penulis yang menegaskan identitas seseorang sebagai hybrid - cangkokan- yang dihasilkan dari pencampuran budaya atau karakteristik dan aspek-aspek budaya dalam diri seseorang dengan lingkungan sekitarnya (Gilbert, 2010).

Dalam konstruksi identitas budaya kolektif diperlukan pemahaman mengenai sejarah budaya atau dalam terminologi Gilbert disebut a chronicle culture. Di sini setiap individu memiliki kesempatan yang sama untuk berpartisipasi dalam sebuah cerita. Narasi identitas dari setiap individu dapat menjadi kontribusi untuk merangkai sejarah budaya bersama suatu komunitas. Demikian, identitas budaya secara kolektif, dalam konsep chronicle culture, dikonstruksikan sebagai suatu narasi identitas yang dimiliki secara bersama. Identitas budaya yang dikonstruksi dari chronicle culture dapat disebut sebagai rasa identitas budaya yang pasti karena didasarkan pada pengetahuan yang asli bukan mistik (Gilbert, 2010).

Konsep teoritis mengenai memori kolektif dan identitas kultural yang disajikan di atas dapat menjadi suatu kerangka teoritis dalam menganalisis pengalaman masyarakat di Negeri (Desa) Batumerah yang plurar penduduknya baik etnik maupun agama. Sebagaimana yang telah dijelaskan secara teoritis bahwa memori kolektif dan identitas kultural itu tersimpan di dalam diri setiap individu atau komunitas masyarakat, sehingga perlu direfleksikan, dihidupkan atau diaktifkan kembali untuk membangun kehidupan bersama. Refleksi terhadap memori kolektif masyarakat terkait pengalaman konflik dan proses damai dikonstruksikan di dalam tiga fase, yakni sebelum konflik, saat konflik, dan sesudah konflik. Klasfikasi ini dimaksudkan untuk menemukan jalinan makna memori kolektif dan identitas kultural dalam membangun hidup bersama.

\section{Harmoni Dalam Perbedaan: Memori Kolektif Pra-Konflik}

Negeri Batumerah berada di pesisir pantai teluk Ambon. Sebelum konflik, negeri ini dihuni oleh penduduknya yang majemuk. Negeri ini merupakan bagian wilayah administratif dari pusat kota Ambon. Jarak tempuh dari negeri Batumerah ke pusat pemerintahan kecamatan Sirimau adalah 1. 50 $\mathrm{Km}$., dan jarak ke pusat pemerintahan kota Ambon adalah $1 \mathrm{Km}$. Akses transportasi menuju negeri Batumerah dapat dijangkau dengan kendaraan bermotor, becak atau pun berjalan kaki. Luas wilayah pemukiman negeri Batumerah secara keseluruhan adalah 1. 277. $738 \mathrm{Ha} / \mathrm{M}^{2}$ yang di dalamnya terdapat beberapa kampung pemukiman yaitu: Pandan Kasturi, Tantui, Galunggung, Kebun Cengkeh dan Air Kuning yang masing-masing dikepalai oleh seorang kepala negeri.

Sesuai dengan kebijakan Perwilayahan Kota Ambon, negeri Batumerah termasuk dalam satuan Wilayah Pengembangan Pembangunan (SWPP), Sub Wilayah pusat kota dan sekitarnya (sebagian negeri Amahusu sampai Latta), yang akan terus ditingkatkan dan dikembangkan sebagai pusat penyelenggaraan pemerintahan, perdagangan, industri perikanan, aneka industri kerajinan rakyat, jasa dan perhubungan laut. Konteks kewilayahan ini menjadikan negeri Batumerah sebagai rumah bersama yang didiami oleh masyarakat dari berbagai suku dan etnik, seperti Jawa, Sulawesi, Kalimantan, Sumatera, dan Maluku.

Sebelum terjadi konflik pada tahun 1999, di negeri Batumerah telah hidup secara berdampingan komunitas masyarakat Islam dengan komunitas masyarakat Kristen. Perbedaan agama sejak lama tidak menjadi masalah, justru memperlihatkan suatu harmoni kehidupan. Tidak hanya terdapat gedung-gedung masjid, tetapi juga terdapat gedung-gedung gereja di tengah pemukiman warga. Berangkat dari sejarah terbentuknya negeri Batumerah, proses integrasi masyarakat berbeda agama yang hidup secara bersama merupakan bagian dari penataan kependudukan sejak era kolonial Belanda berkaitan dengan sejarah berdirinya negeri Batumerah yang telah dijelaskan sebelumnya. Menurut Imam Masjid Agung A'Nur, Hj. Usman Oei, Masjid Agung A'Nur sebagai masjid tua di Batumerah mulai didirikan oleh seorang dermawan yang bernama Hasan Soeleman pada tahun 1875, ketika itu sebagian masyarakat negeri Batumerah telah memeluk agama Islam (Oei, wawancara, 22-02-2018). 
Selanjutnya berdasarkan data sejarah jemaat GPM Bethabara, disebutkan bahwa keberadaan orang Kristen di Batumerah yang sebagian besar merupakan warga Jemaat GPM Bethabara, baru dilembagakan secara organisatoris sebagai suatu jemaat mandiri pada tanggal 06 September 1983. Walau demikian, umat Kristen telah berada bersamaan dengan umat Muslim ketika negeri Batumerah dibangun. Sebelumnya wilayah Jemaat GPM Bethabara yang berada di Negeri Batumerah merupakan kesatuan wilayah pelayanan Jemaat GPM Bethel. Oleh karena luasnya wilayah pelayanan dengan jumlah warga jemaat yang begitu banyak, maka pada Persidangan Jemaat GPM Bethel tahun 1979, dan Persidangan Klasis Kota Ambon di tahun yang sama, direkomendasikanlah proses pemekaran dan pelembagaan Jemaat GPM Bethabara terpisah dari Jemaat GPM Bethel. Kemudian dalam persidangan BPL Sinode GPM tahun 1980, rekomendasi tersebut disetujui sehingga dilakukanlah persiapan dan proses pemekaran pada tahun 1983, dengan kepemimpinan Jemaat pertama pada waktu itu adalah Pdt. M. Lawalata dan Pdt. Lies Marantika (Renstra Jemaat GPM Bethabara, 2015).

Perjumpaan dan hidup masyarakat Batumerah yang beragama Kristen dengan Muslim di kala itu sangatlah harmonis. Imam Oei mengisahkan bahwa toleransi dan kerukunan antar agama yang berbeda di negeri Batumerah selalu menjadi ikon perdamaian di Maluku. Masyarakat dapat hidup saling berbaur, saling berinteraksi layaknya sebagai sesama orang basudara tanpa memandang perbedaan agama. Meski di Batumerah ada percampuran penduduk berbeda agama, namun bukan suatu persoalan pada masa itu, melainkan suatu kekuatan membangun hidup bersama sehingga turut berkontribusi bagi terciptanya tatanan hidup orang basudara di Maluku. (Oei, wawancara, 22-02-2018).

Pdt. I. Toisuta, Ketua Majelis Jemaat GPM Bethabara yang memimpin Jemaat ini pada masa konflik juga mengungkapkan memori kolektifnya mengenai perjumpaan orang basudara di negeri Batumerah. Menurut Toisuta, sebelum konflik terjadi hubungan antara orang Kristen dan Muslim di Batumerah sangat baik. Hubungan tersebut terjalin dalam berbagai bentuk, baik dalam aktivitas hidup sehari-hari di mana masyarakat saling berkomunikasi dan berbaur, maupun dalam perayaan-perayaan hari-hari besar keagamaan di mana masyarakat berbeda agama ini pun saling mendukung kelancaran dan kelancaran setiap pelaksanaan hari-hari besar keagamaan. Demikian Toisuta mengatakan:

Sebelum konflik itu hubungan Jemaat Bethabara dan Batumerah itu sangat baik. Terjalin hubungan saling menghormati dan saling menghargai. Hubungan itu sangat bagus sekali. Setiap hari raya umat Muslim, yang Kristen ikut merayakan, begitu juga sebaliknya. Tradisi saling pegang tangan, silahturami, saling mengunjungi sangat baik. Tidak hanya dalam acara ritual atau seremonial seperti ini, sebelum konflik kita sudah hidup masuk keluar (Saling berdampingan), jadi hubungan setiap hari sebagai sesama orang basudara selalu terwujud, misalnya saling memberi dan menerima atau saling membantu untuk kebutuhan hidup sudah menjadi suatu tradisi (Toisuta, wawancara, 02-04-2018).

Perjumpaan dalam aktivitas hidup setiap hari terjalin mulai dari antara sesama orang tua sampai dengan anak-anak yang saling bergaul dan berteman. Ibu WS, salah seorang warga Jemaat GPM Bethabara, yang sejak jemaat ini didirikan telah hidup bersama keluarganya berbaur dengan basudara Muslim di Batumerah, menceritakan bahwa hubungan antara orang Kristen dan Muslim di Batumerah merupakan suatu hubungan "tampa garam" (tempat menaruh garam). Dalam tradisi masyarakat di Maluku sejak dahulu, di setiap meja makan selalu terdapat suatu wadah kecil yang berisikan garam. Di wadah ini, semua anggota biasanya akan duduk makan bersama, dan secara bergantian mencelupkan salah satu jari tangan masing-masing di wadah tampa garam, lalu dirasakan di mulut masing-masing. Ini merupakan simbol saling merasakan apa yang dirasakan oleh setiap orang bersaudara. Atau dalam ungkapan yang sangat terkenal dari budaya hidup orang basudara di Maluku, yaitu ale rasa, beta rasa.

Menurut pengalaman hidup bersama oleh Ibu WS, hubungan tampa garam antara masyarakat Kristen dan Muslim di Batumerah yang saling berbaur ini terwujud secara nyata dan alami, misalnya dalam hal-hal sederhana seperti saling meminta dan memberi garam untuk memasak atau mengisi tampa garam di meja makan, saling meminta dan memberi bumbu-bumbu masaka, ikan, sayur antara ibu-ibu yang tinggal saling bertetangga. Perjumpaan dan hidup bersama dirayakan sebagai suatu keluarga yang saling menyayangi. Demikian Ibu WS mengatakan: 
Hidup bersama dengan basudara Muslim di Batumerah sudah seperti satu keluarga. Hubungan itu terjalin antara orang tua maupun anak-anak yang selalu pergi bermain dan bersekolah bersama sebagai teman. Antara orang tua, misalnya Ibu-Ibu yang saling bertentangga selalu ada kebiasaan yang saling meminta dan memberi bumbu-bumbu dapur, ikan, sayur yang lebih selalu dibagikan. Sampai dengan isi tampa garam bisa didapat dari sesama orang basudara yang berbeda agama (WS, wawancara, 27-03-2018).

Makna persaudaraan masyarakat Kristen dan Muslim di Batumerah juga diperkuat dan dipengaruhi oleh hubungan pernikahan antar keluarga yang berbeda agama. Jauh sebelum peristiwa konflik, telah terbina hubungan persaudaraan antar masyarakat oleh karena pernikahan orang tua yang berbeda agama, dan tetap menjalin hidup harmonis yang terus diwariskan kepada setiap anakcucu. I.P., seorang tokoh masyarakat Muslim di Batumerah, yang juga menjadi salah satu Ketua RW, menjelaskan bahwa di wilayahnya banyak sekali jalinan hubungan persaudaraan yang merupakan warisan dari pernikahan para orang tua yang sebelumnya berbeda agama. I.P dan keluarganya merupakan salah satu contoh. Keluarga besarnya yang beragama Islam di Batumerah memiliki jalinan hubungan persaudaraan yang kokoh degan keluarga yang beragama Kristen di Passo dan di daerah Lease. Hal ini terjadi karena kakek dari I.P pada awalnya beragama Kristen dan ketika menikah kemudian memeluk agama Islam. Perbedaan agama kedua keluarga besar bukan suatu masalah, melainkan suatu peluang membangun hidup persadaraan yang saling melengkapi. I.P menjelaskan hubungan orang basudara di Maluku justru telah hidup lama sejak para leluhur seperti yang tebingkai dalam ikatan budaya pela-gandong, dan hal tersebut tidak bisa tergantikan. Demikian I.P menyatakan:

Salam sarane (Islam dan Kristen) itu sudah dari dulu. Saya punya kakek dulu seorang Kristen. Namun ketika menikah maka menjadi Islam mengikuti istri. Hal ini bukan masalah, sebab hingga sekarang ini, anak cucu, keluarga kami di Kristen dan Islam tetap bersatu dan saling membantu. Salam-sarane di Maluku tidak ada perbedaan antara satu dengan yang lain. Karena itu kita semua basudara, gandong. Budaya itu memang dari leluhur. Kalau soal agama, ya masing-masing. Tapi kalau identitas budaya sebagai orang basudara, semuanya turun dari para leluhur, yang harus tetap dilestarikan (Parera, wawancara, 24-04-2018).

Dengan demikian, memori perjumpaan dan hubungan orang basudara antara masyarakat Kristen dan Muslim di Batumerah masih membekas dan telah mengkonstruksi suatu identitas historis bahwa sekalipun mereka hidup berbeda agama, tetapi mereka mampu menjalin hubungan sebagai sesama orang basudara, yang tidak sebatas dalam seremonial dan ritual keagamaan, tetapi juga dalam aktivitas hidup keseharian, seperti ungkapan persaudaraan tampa garam, ale rasa, beta rasa. Ini merupakan suatu modal kultural yang tertanam dalam sanubari masyarakat untuk membangun suatu kultur damai.

\section{Memori Hidup Orang Basudara di Tengah Konflik}

Kenyataan hidup orang basudara antara masyarakat Kristen dan Muslim di Batumerah mengalami suatu ujian di tengah peristiwa konflik Maluku yang terjadi berawal di wilayah Batumerah. Berdasarkan data laporan Pemerintah Provinsi Maluku kepada Pemerintah Pusat, yang diberitakan kembali oleh Harian Kompas, 21 Januari 1999, dan dikutip oleh Tonny Pariela dalam kajian disertasinya, "Damai di Maluku", dijelaskan bahwa konflik Maluku berawal dari peristiwa berikut:

Yopi Saiya dan Fery Mual, yang beragama Kristen bersama dua teman preman lain, sambil membawa parang memasuki Desa Batumerah untuk mencari seorang penduduk Batumerah. Karena tidak menemui orang yang dicari, Yopie dan rekan-rekannya menganiaya Mohamad Bugis yang saat itu sedang duduk di pinggir jalan. Warga Batumerah yang saat itu (19 Januari 1999) sedang merayakan Lebaran secara spontan keluar dengan senjata tajam spontan keluar dan ikut mengejar Yopie bersama rekan-rekannya sampai ke perbatasan Desa Mardika. Namun tidak berhasil. Kemudian massa asal Batumerah membakar dua rumah penduduk Mardika yang beragama Kristen dan satu bengkel. Sebelumnya, peristiwa konflik dimulai karena salah seorang penduduk Batumerah meminta uang kepada Yopie. Namun Yopie tidak memberi uang, ia 
kemudian dipukul oleh orang Batumerah tersebut. Kemudian Yopie dan kawannya mencari orang Batumerah itu untuk melakukan pembalasan (Pariela, 2008).

Pertanyaannya, bagaimana peristiwa kriminal biasa dapat dengan mudah berkembang menjadi konflik luar biasa yang secara cepat menyebar dari satu titik ke seluruh wilayah Maluku? Para peneliti konflik Maluku menyebutkan ada banyak faktor yang berperan meningkatkan eskalasi konflik di Maluku, antara lain; konflik Maluku dipandang sebagai akibat dari adanya politik pertentangan di kalangan elit pasca reformasi ( Pieris, 2004). Konflik Maluku sangat mudah menyebar karena adanya potensi konflik terpendam sebagai warisan sejarah kolonial yang mensegregasikan masyarakat Maluku berdasarkan agama (Trijono, 2001; Pariela, 2008). Selain itu, entitas adat dengan pranata budaya hidup orang basudara seperti pela-gandong yang diharapkan menjadi katub pengaman relasi antar masyarakat, ikut mengalami pelemahan akibat diberlakukannya kembali Undang-Undang Nomor 5 Tahun 1979 tentang pemerintahan Desa. Konflik Maluku yang semula merupakan konflik sosial, akhirnya muncul sebagai konflik yang menggunakan simbol-simbol agama. Konflik itu sulit diatasi karena perbedaan muatan idiologi agama dijadikan instrumen memicu dan menyebarkan konflik. Masing-masing pemeluk agama saling mengklaim kebenarannya dan saling menyalahkan. Dalam konflik, simbol-simbol agama dikorbankan misalnya dengan pembakaran gedung gereja atau masjid oleh para perusuh, untuk menyulut emosi masing-masing pemeluk agama terlibat dalam konflik (Pieris, 2004).

Hal ini juga dialami oleh masyarakat Batumerah yang beragama Kristen dan Muslim. Konflik yang bermula terjadi di wilayah Batumerah sangatlah berdampak pada relasi hidup orang basudara antara Jemaat Bethabara dengan Penduduk Muslim di Batumerah. Peristiwa konflik ini terjadi di saat umat Muslim di Indonesia sedang merayakan Hari Idul Fitri. Bersamaan dengan itu, Jemaat GPM Bethabara sedang melangsungkan persidangan Klasis Kota Ambon di Jemaat tersebut. Peristiwa konflik yang bermula dari aksi pemalakkan dapat berubah dengan cepat kepada isu konflik antar umat beragama oleh kuatnya provokasi konflik yang berkembang di tengah masyarakat.

Di wilayah Batumerah, yang pada mulanya hidup sangat harmonis dan rukun, oleh aksi provokasi konflik yang mempengaruhi masyarakat, menyebabkan sebagian besar Jemaat Bethabara harus segera mengungsi dari wilayah Batumerah. Menurut Pdt. I. Toisuta, selaku ketua Majelis Jemaat Bethabara, dorongan untuk masyarakat Kristen mengungsi terutama karena situasi ketegangan konflik yang semakin meningkat, dan bukan karena desakan basudara Muslim di Batumerah. Menurutnya, ketika peristiwa konflik berlangsung di Batumerah tidak hanya terdapat penduduk Muslim lokal, tetapi telah menyusup masuk orang-orang Muslim dari luar Maluku. Toisuta menjelaskan:

Masyarakat Kristen dan Muslim di Batumerah sudah berdampingan seperti saudara sangat lama. Namun, provokasi yang begitu kuat, membawa isu agama ke dalam konflik, sama seperti tekanan dan provokasi orang-orang luar terhadap basudara Muslim Batumerah mengakibatkan ketegangan konflik semakin meningkat. Dalam kondisi ketegangan, basudara Muslim lokal tidak bisa berbuat banyak, dan basudara Kristen harus menghindari konflik, sehingga kita memilih untuk mengungsi (Toisuta, wawancara, 02-04-2018).

Tekanan masa dari luar dan provokasi yang menyeret sentimen agama ke dalam konflik memiliki kekuatan yang dapat mempengaruhi emosi masyarakat di saat konflik terjadi. Memori hidup orang basudara yang telah terbangun sebelum konflik seakan tenggelam di tengah menguatnya teriakanteriakan suara amarah disertai berbagai kejadian tragis yang dialami dalam peristiwa konflik. Masa dari luar Maluku yang menginginkan konflik dan para provokator adalah orang-orang yang tidak mengalami dan menghidupi budaya hidup orang basudara. Aksi dan tindakan mereka justru untuk menghancurkan semangat persaudaraan yang telah terbangun.

Seorang tokoh pemuda di Jemaat GPM Bethabara, ET menjelaskan bahwa pada saat konflik Maluku terjadi, rasa persaudaraan itu sempat terkubur oleh emosi dan amarah yang membuat 
masyarakat saling berkonflik. Emosi dan amarah itu muncul ketika masyarakat menyaksikan dan mengalami berbagai peristiwa dalam konflik. ET sendiri menceritakan pengalamannya demikian.

Saya pada saat terjadinya konflik masih berpikir hanya peristiwa biasa. Namun bertambah hari bertambah parah, banyak rumah dibakar, ada yang terluka, dan bahkan meninggal. Saya sendiri yang sedang melerai teman-teman pemuda untuk tidak berkonflik, tiba-tiba terkena serangan anak pana yang untungnya hanya di kain celana. Sejak itu saya berpikir jika tidak berjuang dan berperang maka saya sendiri yang akan jadi korban. Akhirnya saya terlibat mulai dari merakit bom, sampai dengan ikut berperang. Sampai saat ini saya seiring merenung apakah ada korban jiwa yang disebabkan lemparan bom saya (ET, wawancara, 27-03-2018).

Peristiwa konflik menghadapkan masyarakat pada situasi dan pilihan menjadi pelaku atau korban. Konflik bertahan dan eskalasinya bertambah karena masyarakat memilih untuk menjadi pelaku demi terhindar daripada menjadi korban. Menurut ET ketika terjadi konflik memori persaudaraan yang hidup hanyalah kepada orang-orang terdekat, yang telah lama menjalin hubungan persaudaraan sejak kecil hingga besar menjalin hidup bersama. ET memandang saudaranya yang berbeda agama hanyalah kepada para tetangga rumahnya dan teman-teman sekolah yang hidup bergitu ramah dan baik sebelum konflik. Masyarakat Muslim lainnya telah dianggap sebagai lawan dalam konflik, yang harus diperangi. ET mengatakannya demikian.

Dalam emosi konflik, mereka yang tetap dianggap saudara selain saudara kandung, adalah teman-teman dekat dengan keluarganya. Mereka ini telah hidup bersama sejak lama sebelum konflik. dan mereka ini juga tidak ingin berkonflik tentunya. Orang tua kita selalu menasihati untuk saling menyayangi sebagai saudara walaupun kita berbeda agama. Nasihat ini tentu kita pegang. Selama konflik pun kita saling berkomunikasi. Sedangkan yang lain, sulit sekali dianggap saudara sebab belum tentu mereka anggap kita juga saudara. Jadinya kita saling berperang (ET, wawancara, 27-03-2018).

Persaudaraan di dalam konflik memang seperti benih yang harus bertahan di tengah semak duri. Persaudaraan itu bertumbuh namun banyak hambatannya, terutama oleh provokasi dan eskalasi konflik yang meningkat. Namun benih persaudaraan itu memiliki akar historis-kultural yang kuat sehingga tidaklah mati. Di tengah konflik bahkan ada pula memori-memori persaudaraan yang mekar. I.P., seorang ketua RW yang dianggap sebagai salah satu tokoh masyarakat Batumerah, mengisahkan perjuangannya untuk melakukan rekonsiliasi di tengah situasi konflik yang memanas pada tahun 1999. Pada saat konflik terjadi pertama kali, rumahnya sementara dipenuhi oleh para sahabat dan saudarasaudaranya beragama Kristen yang turut merayakan Idul Fitri dengan bersilahturami. Sampai larut malam ketika basudara yang beragama Kristen itu terjebak di rumahnya, I.P. bersama para pemuda di wilayah RT/RW itu berinisiatif untuk mengantarkan para basudara Kristen keluar dari wilayah ketegangan dan konflik yang hanya berjarak 100 Meter dari rumahnya.

Kemudian pada tahun 1999 juga ketika eskalasi konflik yang meningkat turut memaksa basudara dari Jemaat Bethabara harus meninggalkan wilayah Batumerah, I.P. bersama dengan tokoh agama mengambil inisiatif untuk mengajak basudara Kristen kembali dan membangun persekutuan melalui acara makan patita damai. Acara ini berjalan dengan baik, turut menghadirkan para pemimpin daerah saat itu, dan bersama dengan semua masyarakat, dua komunitas agama meneguhkan komitmen untuk tetap menjaga ikatan persaudaraan yang terbangun sejak para leluhur, dan berjuang untuk perdamaian. Namun demikian, usaha I.P dan para tokoh agama ini dihadapkan dengan eskalasi konflik yang terus meningkat di berbagai wilayah, bersamaan dengan kuatnya arus provokasi konflik dari orang luar, sehingga konflik di wilayah itu pun tidak terelakan (I.P., wawancara, 24-04-2018).

Memori hidup basudara yang membentuk identitas budaya masyarakat Batumerah sebagai sesama orang basudara tetap bertahan di tengah situasi konflik. Memori ini tidak segera memadamkan api konflik, karena eskalasi dan provokasi konflik yang semakin meningkat dan tersebar di hampir seluruh wilayah di Maluku. Namun, memori ini menjadi modal kulurtural yang merajut kembali 
perdamaian dan keharmonisan hidup sebagai sesama orang basudara. Bahkan, identitas kultural yang mengakar pada benih persaudaraan yang tumbuh di tengah situasi konflik menjadi suatu kekuatan perekat dan penjaga perdamaian yang dibangun di masa kini.

\section{Merawat Damai Melalui Memori Hidup Orang Basudara}

Pluralistas masyarakat, seperti yang terdapat di Maluku, secara khusus yang dihidupi oleh masyarakat Batumerah yang berbeda agama, meminjam gagasan John Titaley, dapat menjadi tantangan (challenge) sekaligus peluang (opportunity). Tantangan karena keragaman agama-agama dunia dapat menjadi sumber bagi lahirnya konflik yang sangat serius dalm kehidupan bermasyarakat dan bernegara, termasuk juga beragama. Peluang karena kalau keragaman agama itu bisa tertangani secara tepat, kemungkinan konflik itu bisa berubah menjadi dukungan moral, etis dan spiritual yang positif bagi kehidupan bermasyarakat, berbangsa, bernegara dan beragama (Titaley, 2002).

Masyarakat Batumerah, baik komunitas Kristen maupun Muslim telah mengalami keduanya, tantangan dan peluang mengelola kemajemukan hidup beragama. Fondasinya adalah memori hidup orang basudara. Dengan fondasi ini, tantangan konflik mampu dilewati, dan konstruksi identitas kultural hidup orang basudara sebagai peluang merajut harmoni dan damai dapat dibangun lagi. Agama-agama memiliki tatanan nilai moral, etis dan spiritual yang mendukung nilai-nilai hidup orang basudara, sebagaimana yang terwariskan dalam kultur hidup persaudaraan di Maluku. Oleh karena itu, peluang membangun budaya damai, yang berbasis pada nilai-nilai agama dan budaya yang mulia, telah diwujudkan dalam perdamaian di Maluku. Ini merupakan sumbangan berharga suatu pelajaran dari situasi konflik bagi kehidupan masyarakat di masa kini.

Konstruksi memori hidup bersama sebagai sesama orang basudara baik sebelum konflik maupun di masa konflik bertujuan untuk meneguhkan kembali akar identitas budaya yang dapat menyuburkan hubungan persaudaraan antar masyarakat sehinga berkontribusi merawat proses perdamaian di masa kini dan masa yang akan datang. Pengalaman hidup sebagai orang basudara yang terjalin sejak para leluhur, terawat di tengah tekanan situasi konflik, dan memberi kontribusi besar dalam upaya perdamaian, merupakan suatu modal sosial untuk terus membangun budaya damai dalam hidup bersama masyarakat Maluku.

Perdamaian Maluku yang diharapkan terbangun bukan semata sebagai suatu kondisi tanpa konflik dan kondisi aman yang temporer, melainkan suatu kontruksi budaya yang dihidupi dan diwariskan nilai-nilainya dalam hidup semua generasi masyarakat Maluku. Budaya damai menjadi suatu kontruksi akal budi yang berangkat dari nilai-nilai luhur dan kearifan lokal masyarakat Maluku yang mengedepankan pentingnya hidup orang basudara. Dalam budaya damai, tertib hidup dan rasa saling bersaudara, ale rasa beta rasa, satu tampa garam, potong di kuku rasa di daging, dan seterusnya menjadi wejangan normative yang menuntun cara berlaku hidup orang basudara seorang dengan yang lain.

La De, seorang pengurus masjid Batumerah, yang sudah 60 tahun lebih hidup di Maluku, sebagai seorang yang berasal dari Buton, mengakui bahwa hidup persaudaraan di Maluku sangatlah indah. Rasa persaudaraan di Maluku membuat orang yang datang dari luar pun terisap masuk dan dapat menjadi bagian yang menghidupi kultur persaudaraan tersebut. Hal ini dapat terjadi jika masyarakat dari luar benar-benar ingin menerima dan menjadi bagian identitas budaya hidup orang basudara di Maluku. La De yang berprofesi sebagai seorang tukang becak keliling, merasa bahwa ia memiliki banyak saudara lintas iman. Persaudaraan lintas iman itu dibangun dalam aktivitas hidup setiap hari, melalui perbuatan yang saling membantu dan menolong. Menurut La De, masyarakat Maluku sangat cepat menerima seseorang sebagai saudara asalkan orang itu juga mau bertindak dan berlaku sebagai sesama saudara. Dalam peristiwa konflik, La De yang menyadari dirinya hanya seorang masyarakat biasa lebih memilih untuk menjalani hidup dengan berbajukan persaudaraan, dan tetap berdoa untuk perdamaian Maluku.

Nilai hidup persaudaraan mengajarkan masyarakat Maluku untuk saling membantu (bakubantu) saling menyayangi (bakusayang), saling berdamai (bakubae), dan bukan saling membunuh (bakubunuh). Justru budaya hidup orang basudara yang terbingkai dalam pranata pela keras (pela darah) atau ikatan 
gandong, yang terjadi adalah para leluhur saling meminum darah sebagai akta perjanjian ikatan pelagandong, hidup orang basudara yang tidak boleh saling menumpahkan darah(Parihala, Samson, \& Tika Lestari, 2019).

Dalam kaitan itu, Pdt. I. Toisuta menceritakan bahwa dalam peristiwa konflik, seorang anaknya yang sulung, yang mestinya melanjutkan karirnya sebagai seorang pendeta, juga menjadi korban penculikan dan dibunuh oleh mereka yang tidak bertanggung jawab. Ini adalah peristiwa yang sangat memilukan hatinya, dan masih tetap dikenang. Namun, menurut Toisuta, kematian anaknya adalah korban bagi tegakknya keadilan, kedamaian dan persaudaraan di Maluku. Kematian anaknya hendak menegaskan bahwa "sampai jua" jangan lagi membunuh anak-anak generasi masa depan Maluku, marilah berdamai, agar kita tidak menjadi debu. Hal ini yang selalu diungkapkan oleh Toisuta dalam memaknakan kematian putra sulungnya. Toisuta hanya bisa menyerahkan kasus ini untuk ditangani oleh pihak kepolisian (Toisuta, wawancara, 02-04-2018).

Perdamaian yang dibangun di atas dasar memori persaudaraan memang merupakan perdamaian yang sangat berharga. Perdamaian ini bahkan tidak dapat mengabaikan peristiwa konflik yang telah memakan begitu banyak korban jiwa, harta benda, bahkan korban relasi dan kontruksi hidup persaudaraan. Demikian membangun perdamaian perlu disertai dengan perjuangan menegakkan hukum, keadilan, kesetaraan, di mana semua orang harus diperlakukan sama di hadapan hukum. Budaya hidup orang basudara menegaskan pentingnya membangun hidup yang sesuai dengan norma-norma yang berlaku di tengah masyarakat demi keteratuan hidup.

Konsep orang basudara atau pada umumnya dikenal oleh masyarakat Maluku dengan hidup orang basudara adalah suatu cara hidup yang menempatkan diri sesama anak negeri Maluku baik yang berbeda pulau, bahasa maupun agama di dalam sebuah keutamaan hidup sebagai saudara sekandung untuk hidup saling peduli - baku kalesang, saling mengasihi - baku sayang, saling berdamai - baku bae. Saudara sekandung memiliki konotasi makna yang hakiki bahwa semua anak negeri atau masyarakat Maluku berasal dari kandungan ibu pertiwi yang bernama Maluku. Makna ini dapat ditemukan dalam mitos, kisah, nyanyian kapata - atau musik lokal Maluku, dan serpihan-serpihan tradisi dari masa lalu yang tetap bertahan dalam ingatan kolektif. Tradisi-tradisi tersebut menunjukkan kepercayaan asli terhadap kesatuan mistis yang dikenal sebagai Maluku, yang menghubungkan seluruh pulau dengan banyak ragam komunitas etnolinguistik sebagai satu keluarga (van Fraassen \& Andaya, 1994).

Masyarakat Batumerah baik yang beragama Islam maupun Kristen, sesungguhnya tetap menyadari identitas kolektif mereka sebagai sesame orang basudara. Kendati konflik Maluku kini telah memisahkan ruang hidup mereka, namun nilai-nilai dan makna hidup sebagai sesame orang basudara tetap terpatri dalam sanubari setiap masyarakat. Ini adalah modal sosial-kultural menjaga dan merawat perdamaian di negeri Maluku.

\section{Simpulan}

Memori dan identitas kultural sebagai sesama orang basudara dalam konteks hidup masyarakat Batumerah diperhadapkan dengan benturan konflik Maluku, yang ingin menghancurkan tatanan hidup orang basudara melalui provokasi konflik dengan menggunakan simbol-simbol agama. Walau demikian, identitas kultural sebagai sesama orang basudara tetap tersimpan di dalam memori kolektif setiap masyarakat. Identitas tersebut pun bermakna dalam membangun hidup yang saling baku sayang, saling baku bae, dan bukan baku bakalae atau baku musuh. Makna hidup ini kemudian menjadi suatu imperatif moral yang mendorong masyarakat Maluku untuk mengupayakan proses perdamaian. Terlepas dari berbagai pendekatan rekonsiliasi, rehabiliatasi dan pendekatan keamanan yang dilakukan untuk mewujudkan perdamaian, sesungguhnya kesadaran kolektif di dalam identitas kultural masyarakat bahwa mereka adalah orang basudara merupakan fondasi bagi tegaknya proses membangun perdamaian di Maluku. Kesadaran yang lahir dari ingatan bersama sebagai anak negeri Maluku, sebagai sesama orang basudara, menjadi modal sosial-kultural yang mesti diperkuat untuk terus menjaga dan merawat perdamaian di Maluku. 


\section{Referensi}

Al-Qurtuby, S. (2011). Interligious Violence, Civic Peace, and Citizenship Christian and Muslims in Maluku Eastern Indonesia. Boston University.

Al Qurtuby, S. (2013). Peacebuilding in Indonesia: Christian-Muslim Alliances in Ambon Island. Islam and Christian-Muslim Relations. https://doi.org/10.1080/09596410.2013.785091

Bräuchler, B. (2019). From transitional to performative justice: Peace activism in the aftermath of communal violence. Global Change, Peace and Security. https://doi.org/10.1080/14781158.2019.1585794

Buchanan, C., \& Cooper, A. (2011). Conflict Management in Indonesia - An Analysis of the Conflicts in Maluku , Papua and Poso. Analysis.

Diana F Sabandar, Johan. R. Saimima, \& Yohanes Parihala. (2020). Agama untuk Perdamaian Berdasarkan Interpretasi Lukas 12:39-53 Dari Perspektif Teologi Religionum. ARUMBAE: Jurnal Ilmiah Teologi Dan Studi Agama, 2(1). https://doi.org/https://doi.org/10.37429/arumbae.v2i1.416

Duncan, C. R. (2016). Coexistence not Reconciliation: From Communal Violence to Non-Violence in North Maluku, Eastern Indonesia. Asia Pacific Journal of Anthropology. https://doi.org/10.1080/14442213.2016.1206615

F. Manuputty, J. (2017). Meretas Jalan Damai Berbasis Masyarakat Dan Agama : Dari Maluku Untuk Indonesia Dan Dunia. In I. Ali Fauzi (Ed.), Ketika Agama bawa Damai, Bukan Perang: Belajar dari Imam dan Pastor (Ketika Aga). Jakarta: PUSAD Paramadina.

Foscarini, G. (2018). Collective memory and cultural identity. Ethnologies. https://doi.org/10.7202/1051665ar

Gilbert, P. (2010). Cultural identity and political ethics. In Cultural Identity and Political Ethics. https://doi.org/10.3366/edinburgh/9780748623877.001.0001

Halbwachs, M. (1992). On Collective Memory. In The Heritage of sociology.

Iwamony, R., Gaspersz, S., \& Souisa, N. (2019). To embrace and be embraced: School pela in post-conflict ambon. Studies in Interreligious Dialogue. https://doi.org/10.2143/SID.29.1.3286456

Jacobs, S. (2007). Edward shils' theory of tradition. Philosophy of the Social Sciences. https://doi.org/10.1177/0048393107299685

Jati, W. R. (2013). Kearifan Lokal Sebagai Resolusi Konflik Keagamaan. Walisongo: Jurnal Penelitian Sosial Keagamaan, 21(2), 393. https://doi.org/10.21580/ws.2013.21.2.251

Johan Galtung. (1996). Peace By Peaceful Means: Peace and Conflict, Development, and Civilization. London: SAGE Publication.

John Pieris. (2004). Tragedi Maluku: Sebuah Krisis Peradaban: Analisis Kritis Aspek:Politik, Sosial-Budaya dan Keamanan. Jakarta: Yayasan Obor.

Lambang Trijono. (2001). Keluar Dari Kemelut Maluku. Yogyakarta: Pustaka Pelajar.

Mannitz, S. (2017). The cultural dimension of peace. Decentralization and reconciliation in Indonesia. Peacebuilding. https://doi.org/10.1080/21647259.2017.1324369

Meo, R. L. (2019). Sumbangan Etika Global Hans Küng Demi Terwujudnya Perdamaian dan Relevansinya Bagi Indonesia. Jurnal Ledalero, 18(1), 103. https://doi.org/10.31385/jl.v18i1.157.103-122

Olaf H Schumann. (2011). Agama-Agama, Kekerasan dan Perdamaian. Jakarta: BPK Gunung Mulia.

Pamungkas, C. (2015). Social contexts of exclusionary reactions: Study on Muslim and Christian relation in the city of Ambon. Indonesian Journal of Islam and Muslim Societies. https://doi.org/10.18326/ijims.v5i1.49-78

Parihala, Y., Samson, R. A., \& Tika Lestari, D. (2019). The Education of “Orang Basudara": The Development of Multicultural Education in the Higher Education of Maluku Indonesian Christian University and Its Contribution to Maintain Peace in Maluku. Proceedings of the International Conference on Religion and Public Civilization (ICRPC 2018). https://doi.org/10.2991/icrpc-18.2019.6

Shils, E. (1971). Tradition. Comparative Studies in Society and History. https://doi.org/10.1017/S0010417500006186

T. Pariela. (2008). Damai di Maluku. Salatiga: Satyawacana University Press.

Tika Lestari, D. (2019). Religious Conflict Transformation through Collective Memory and the Role of Local Music. https://doi.org/10.2991/icrpc-18.2019.22

Titaley, J. (2002). The Pancasila of Indonesia: A Lost Ideal? In Faith and Ethnicity. https://doi.org/10.1163/9789004389137_004

van Fraassen, C. F., \& Andaya, L. (1994). The World of Maluku: Eastern Indonesia in the Early Modern Period. Indonesia. https://doi.org/10.2307/3351106

Yusak B Setyawan. (2017). Konflik dan Kekerasan Bernuansa Agama di Indonesia Dalam Perspektif Pandangan Yesus dalam Injil-Injil Kanonis Perjanjian Baru. In Yusak B Setyawan, Nancy Souisa, Seteve Gaspersz, \& Ratnawati Lesawengan (Eds.), Perdamaian dan Keadilan (pp. 1-36). Jakarta: BPK Gunung Mulia. 
(C) 2020 by the authors. Submitted for possible open access publication under the terms and conditions of the Creative Commons Attribution 4.0 International (CC BY 4.0) license (https://creativecommons.org/licenses/by/4.0/). 